\title{
PENGEMBANGAN MODEL PENINGKATAN PRODUKTIVITAS USAHA KERUPUK UBI MELALUI KERJASAMA SINERGIS INDUSTRI SKALA RUMAH TANGGA DI KECAMATAN KAMANG MAGEK DAN KECAMATAN BASO, KABUPATEN AGAM, SUMATERA BARAT
}

\author{
Oleh: \\ Dendi Adi Saputra ${ }^{1}$, Adjar Pratoto, Ismet Hari Mulyadi \\ ${ }^{1} J u r u s a n$ Teknik Mesin, Fakultas Teknik, Universitas Andalas \\ 'dendiadisaputra05@gmail.com
}

\begin{abstract}
Abstrak
Kabupaten Agam, Sumatera Barat memiliki produk unggulan berupa kerupuk ubi (singkong), baik untuk konsumsi lokal maupun sebagai oleh-oleh khas Sumatera Barat. Sebagian besar usaha kerupuk ubi merupakan industri rumah tangga (IRT). IRT Karya Muda (mitra 1) telah memiliki jaringan pemasaran yang baik dan telah memiliki label tersendiri, namun seringkali pasokan dari IRT pengolah kerupuk ubi tidak selalu kontinu dan jumlah pesanan sering tidak dapat terpenuhi. IRT Yelmi (mitra 2) merupakan salah satu pengolah kerupuk ubi. Pengolahannya menggunakan perangkat manual. Untuk itu, pada tahun 2015 melalui kegiatan hibah Ipteks bagi Masyarakat DIKTI dilakukan implementasi model peningkatan Produktivitas melalui kerjasama sinergis. Secara khusus, prinsip pengembangan model ini adalah membantu IRT Yelmi untuk meningkatkan lagi kapasitas produksi melalui introduksi teknologi mesin roll press dan cetakan mekanis. IRT Karya Muda akan berbagi resep khusus (ingredients) sesuai dengan ciri khas produknya ke IRT Yelmi. Selanjutnya IRT Yelmi akan memasok kerupuk ubi ke IRT Karya Muda. Dengan kerjasama ini, mitra 2 akan mendapatkan peningkatan pendapatan dan membuka lapangan kerja baru melalui peningkatan kapasitas produksi dan peningkatan standar mutu kerupuk ubi dan mitra 1 akan mendapatkan pasokan produk yang stabil, yang pada gilirannya juga akan meningkatkan pendapatannya.
\end{abstract}

Kata kunci: pasokan, kerupuk ubi, produktivitas, sinergis

\begin{abstract}
Agam, West Sumatra has a superior product in the form of cassava chips, both for local consumption as well as souvenirs typical of West Sumatra. Most of the production of the cassava chips was domestic industry (IRT), one of which IRT Karya Muda (partner 1) has had a good marketing network and has had its own label, but often the supply of IRT processing cassava chips are intermittent and the number of orders often cannot be met. IRT Yelmi (partner 2) is one of processing cassava chips. Processing using the device manually. To that end, in 2015 through the activities of science and technology for the Community grant DIKTI be the implementation model of productivity enhancement through synergistic cooperation. In particular, the principle of the development of this model is to help IRT Yelmi to increase the production capacity through the introduction of technology roll press machine and mold mechanically. The work IRT Young will share a special recipe (ingredients) in accordance with the typical products to IRT Yelmi. Furthermore, Yelmi IRT will supply to the sweet potato crisps Young IRT work. With this partnership, the two partners will get increased revenue and create new jobs through increased production capacity and improved quality standards and sweet potato crisps 1 partners will gain a stable supply of products, which in turn will increase revenue.
\end{abstract}

Keywords: Supply, cassava chips, productivity, synergy

\section{PENDAHULUAN}

Ubi kayu (Manihot utilissima) merupakan tanaman perdu yang banyak ditemui di daerah tropik dan subtropik. Sumatera Barat merupakan daerah yang memiliki potensi yang cukup besar dalam produksi ubi kayu. Pada tahun 2011 produksinya mencapai hampir 192 ribu ton dengan total lahan produksi seluas hampir 5600 ha (Anonim, 2013). Kabupaten Agam merupakan salah satu daerah di Sumatera Barat yang memiliki potensi yang besar dalam pengolahan makanan berbahan dasar singkong. Salah satu usaha pengolahan ubi kayu yang banyak 
dilakukan adalah usaha kerupuk ubi. Selain dipasarkan secara lokal, kerupuk ubi tersebut juga telah dipromosikan sebagai oleh-oleh makanan khas Sumatera Barat. Pada umumnya usaha kerupuk ubi dikelola oleh industri rumah tangga (IRT). Satu IRT minimal mampu menghasilkan produk kerupuk ubi mentah hingga $50 \mathrm{~kg} / \mathrm{hari}$ tergantung dengan teknologi dan kapasitas produksi yang tersedia.

\section{Mitra 1 (IRT Karya Muda)}

IRT Karya Muda merupakan usaha yang bergerak dalam bidang pengolahan, pembuatan dan penjualan kerupuk ubi dengan nama "Kerupuk Ubi Rima". IRT Karya Muda memiliki fasilitas produksi yang berupa mesin roll press dan perangkat pengemasan vakum (vacuum packing). Namun demikian, IRT ini tidak dapat memproduksi sendiri kerupuk ubi karena tidak memiliki tenaga kerja operator mesin. $\mathrm{Di}$ daerah tersebut, sulit mendapatkan tenaga kerja operator yang terampil dan adanya masalah kultural lainnya. Dengan kondisi tersebut, IRT Karya Muda bekerja sama dengan IRT lain untuk penyediaan produk dengan menggunakan resep khas Karya Muda. Produk tersebut kemudian dipasarkan ke distributor besar di kota Padang dengan label milik IRT Karya Muda. Persoalannya adalah tidak banyak IRT lain yang mampu memasok dengan persyaratan yang ditetapkan oleh distributor besar. Persyaratan yang sering diminta adalah masalah kebersihan proses pengolahan. Sebagaimana biasanya,

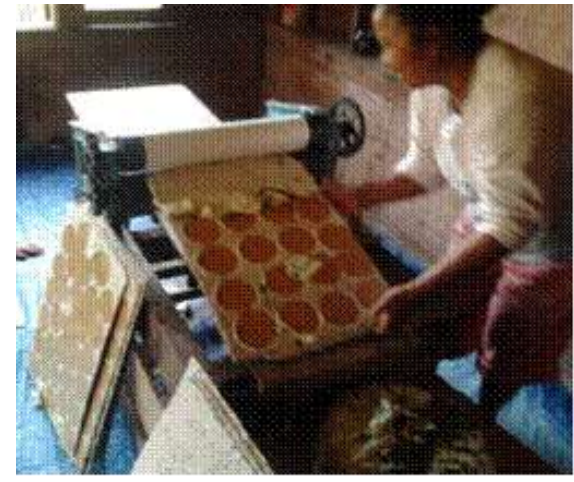

(a) distributor besar akan mengunjungi tempat pengolahan sebelum memesan produk untuk memastikan kebersihannya dalam rangka mempertahankan mutu produk. Dengan kondisi tersebut, IRT Karya Muda seringkali tidak mampu memenuhi pesanan dari distributor besar tersebut.

\section{Mitra 2 (IRT Yelmi)}

IRT Yelmi melakukan usaha kerupuk ubi dengan mengolah pasta ubi menjadi kerupuk ubi mentah. Dalam pengembangan usahanya, IRT Yelmi memliki pekerja yang terdiri dari anggota-anggota keluarga (family workers) yang tidak dibayar. Pengolahan ubi kayu menjadi kerupuk ubi mentah dilakukan melalui beberapa tahapan proses, yaitu pengupasan kulit, perebusan, penumbukan untuk menghasilkan pasta, pengepresan pasta untuk mendapatkan lembaran pasta dengan ketebalan tertentu, pencetakan, dan pengeringan. Bahan kerupuk ubi yang telah dikeringkan tersebut kemudian dipasarkan. Proses press dilakukan dengan menggunakan mesin roll press manual (Gb.1.1a). Dengan mesin press manual ini, kapasitas produksi hanya berkisar $50 \mathrm{~kg}$ pasta ubi/hari. Melalui kegiatan pengabdian kepada masyarakat Universitas Andalas tahun 2013 , dilakukan modifikasi mesin roll press dengan menambahkan sebuah motor listrik (Gb.1.1b). Dengan modifikasi ini, kapasitas produksi dapat ditingkatkan menjadi hingga dua kali lipat, yaitu sekitar 100 kg pasta ubi/hari

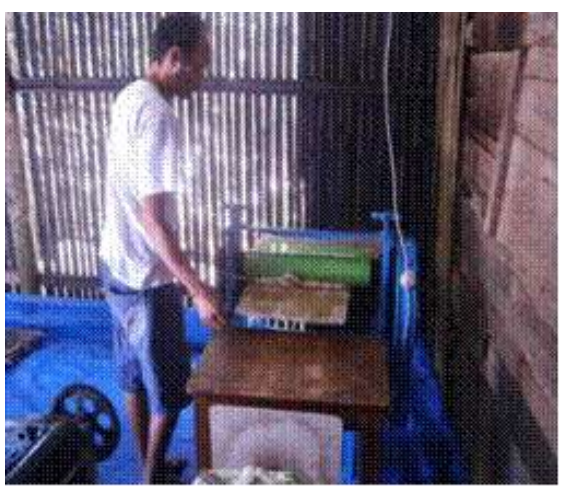

(b)

Gambar 1. Mesin roller pasta ubi, (a) manual (digerakkan dengan tenaga manusia), (b) digerakkan dengan bantuan motor listrik

Dalam pengolahan kerupuk ubi dibutuhkan 2 orang tenaga kerja, 1 orang sebagai operator mesin roll press dan 1 orang sebagai operator pencetakan. 


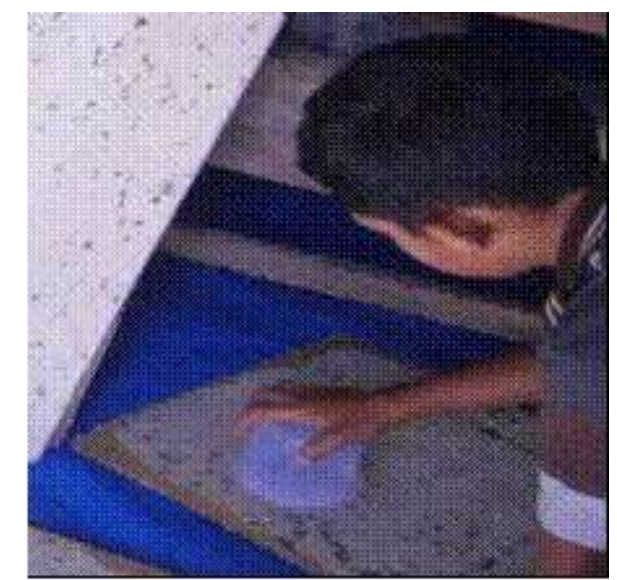

Gambar 2. Proses pencetakan kerupuk ubi

Setelah dilakukan pengepresan, pasta ubi yang telah pipih dicetak secara manual dengan menggunakan cetakan bulat sederhana (Gb.1.2). Proses pencetakan bertujuan untuk membentuk dimensi bulat pada pasta ubi (sesuai permintaan) yang telah dirolling sebelum di atas papan cetakan. Proses ini menjadi proses yang penting dalam proses pembuatan kerupuk ubi karena sebelum dilakukan proses pengolahan selanjutnya, pasta ubi yang dipipihkan harus dipindahkan sesuai dengan cetakannya (bulat) ke tempat pengeringan. Masih manual/konvensionalnya proses pencetakan pasta ubi menyebabkan belum optimalnya produktivitas kerupuk ubi IRT Yelmi. Selain itu, permasalahan pemasaran yang masih dilakukan di pasar tradisional dan distributor lokal menyebabkan harga jual kerupuk ubi mentah menjadi di bawah harga jual pasar (harga jual dari IRT ke pasar tradisional dan distributor lokal Rp. $14.000,-/ \mathrm{kg}$, harga jual dari pasar tradisional dan distributor lokal ke konsumen Rp. 16.000,-/kg). Hal ini berdampak kepada turunnya pendapatan yang seharusnya didapatkan oleh IRT Yelmi.

\section{Tujuan}

Tujuan dari pelaksanaan kegiatan ini adalah untuk mengimplementasikan model kerjasama sinergis melalui introduksi teknologi tepat guna sehingga dapat meningkatkan produktivitas dan pendapatan masing-masing mitra.

\section{METODA PELAKSANAAN}

\section{Penentuan Permasalahan Mitra}

Berdasarkan analisa situasi pada mitra yang sudah dilakukan melalui survei pendahuluan ke IRT Yelmi dan IRT Karya Muda yang berlokasi di Kabupaten Agam dapat diidentifikasi dan dirumuskan permasalahan yang dihadapi kedua mitra dalam produksi usaha kerupuk ubi sebagai berikut:

a. Proses pembuatan kerupuk ubi masih yang dilakukan mitra masih menggunakan metode konvensional (manual) untuk pencetakan dan belum tersentuh aplikasi teknologi mekanikal yang bersifat mediumtechnology, sementara permintaan akan kerupuk ubi belum sepenuhnya terpenuhi dengan baik dan diprediksi akan meningkat disebabkan adanya penambahan peluang pasar yang besar untuk pemasaran hasil produksi.

b. Salah satu rancangan komponen yang dibutuhkan dalam usaha produksi kerupuk ubi adalah cetakan mekanis. Cetakan mekanis merupakan alat bantu untuk melakukan proses pencetakan pasta ubi. Dari pengalaman mitra, proses pencetakan membutuhkan operator khusus yang melakukan proses pencetakan. Operator yang belum mahir akan menyebabkan terbuangnya material pasta ubi yang akan dicetak sehingga peningkatan produktivitas produksi sulit dilakukan.

c. Cetakan manual menggunakan gelas/ kaleng-susu bekas dengan 1 proses cetakan menghasilkan 1 cetakan. Konsekuensinya adalah waktu yang 
dibutuhkan untuk pencetakan
menjadi lama.

d. Tuntutan akan standarisasi produk (resep) dan strandar kualitas proses (kebersihan proses dan peralatan) menjadi suatu persyaratan yang harus dipenuhi oleh kedua mitra agar dapat memperluas daerah pemasaran dan peningkatan nilai tambah dari produk.

\section{Rencana Kegiatan}

Rencana kegiatan yang akan dilakukan adalah sebagai berikut:

1. Identifikasi masalah

Identifikasi masalah dilakukan dengan survei lapangan ke lokasi mitra. Dalam survei ini dilakukan peninjauan kembali proses produksi kerupuk ubi, mulai dari pengolahan bahan baku sampai menjadi kerupuk ubi. Kegiatan wawancara dengan mitra dilakukan untuk mengetahui permasalahan dan keinginan mitra dalam pengembangan usaha kerupuk ubi.

2. Peningkatan produktivitas

Peningkatan

produktivitas dilakukan dengan penambahan mesin roll press dan cetakan mekanis pasta ubi.

\section{a. Perancangan Perangkat}

Dalam perancangan perangkat roller dan cetakan mekanis pasta ubi, ditempuh langkah-langkah berikut diantaranya, Formulasi masalah mitra, perumusan desain awal dan penetapan desain rinci 3.3. (eggert, 2005) untuk mencapai hasil rancangan yang sesuai dengan kebutuhan mitra.

b. Pembuatan (Proses Produksi)

Proses produksi dilakukan di bengkel/workshop yang dekat dengan lokasi mitra yang mampu melakukan proses fabrikasi, seperti pengelasan dan proses permesinan.

\section{c. Introduksi Alat ke Mitra dan} Evaluasi

Peralatan yang telah dibuat, disosialisasikan kepada mitra dengan tujuan untuk mengenalkan dan memberikan informasi mengenai cara penggunaan alat dan standar operasional prosedur dari alat yang dibuat. Evaluasi perangkat dilakukan untuk mengukur performansi dari perangkat yang dibuat. Selain itu, evaluasi terhadap interaksi mesinmanusia juga dilakukan dalam bentuk tingkat kepuasan pengguna.
3. Penyusunan SOP produksi dan proses produksi usaha kerupuk ubi untuk masing-masing mitra.

\section{Partisipasi Mitra}

Untuk menjamin proses implementasi model dapat diterapkan dengan baik, maka masing-masing mitra berkomitmen untuk berpartisipasi dalam menyediakan lokasi dan pekerja untuk turut serta dalam proses perencanaan hingga uji coba prototipe. Masing-masing mitra menyediakan bahan mentah berupa ubi kayu dan peralatan pendukung lainnya seperti tempat pembersihan, perebusan dan pengeringan ubi.

\section{HASIL DAN PEMBAHASAN}

\section{Model Kerjasama Sinergis}

Model kerjasama dikembangkan adalah melakukan kerjasama sinergis antara Mitra 1 dan Mitra 2 terkait dengan pemenuhan kebutuhan kerupuk ubi yang harus dipasok oleh Mitra 1 ke distributor besar. Mitra 1 akan memberikan standar produksi berupa resep pengolahan kerupuk ubi dan standar kontrol kualitas peralatan dan proses pengolahan (kebersihan) kepada Mitra 2. 


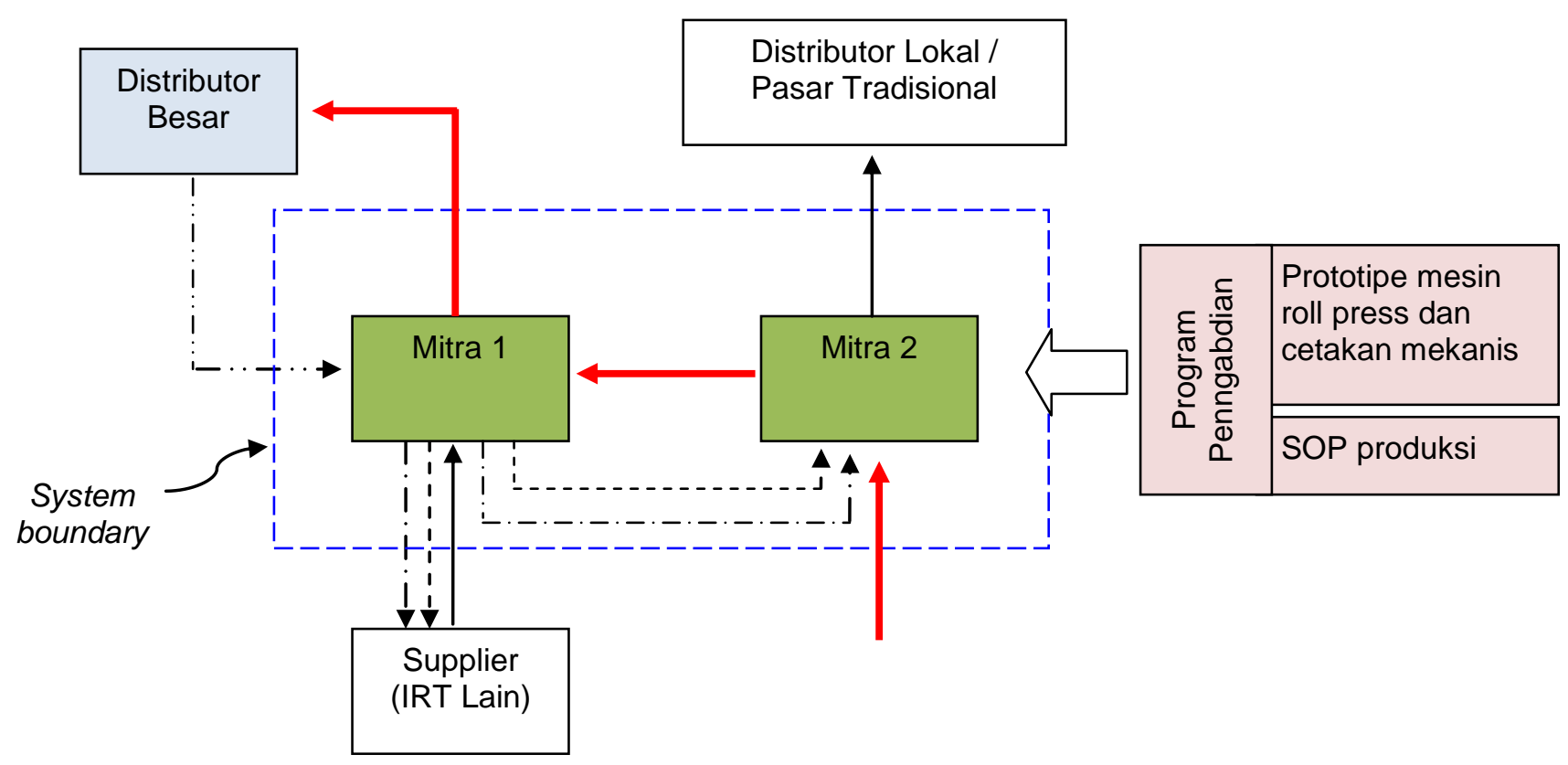

Keterangan garis:

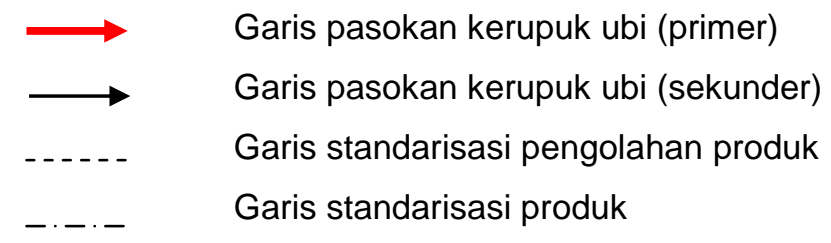

Gambar 3. Model Kerjasama Sinergis Usaha Kerupuk Ubi

Dalam skema kerjasama, prioritas hasil produksi Mitra 2 akan disalurkan ke Mitra 1 dengan harga jual lebih tinggi dari harga pasaran. Jika terdapat sisa hasil produksi, maka Mitra 2 boleh memasarkan hasil produksi ke distributor lokal/pasar tradisional. Adanya mesin roll press dan cetakan mekanis akan meningkatkan produktivitas usaha kerupuk ubi bagi Mitra 2. Hal ini dilakukan karena Mitra 1 telah memiliki relasi dan jaringan pemasaran yang besar untuk menampung produksi kerupuk ubi yang diproduksi. Skema solusi model kerjasama sinergis dapat dilihat pada Gambar 3.

\section{Konsep Perancangan Teknologi}

Mesin pencetak kerupuk ubi yang diusulkan untuk di desain dengan tidak menggunakan motor listrik/ motor bensin. Hal ini ditujukan untuk menekan biaya operasional pembuatan kerupuk, naiknya tarif dasar listrik dan harga BBM. 


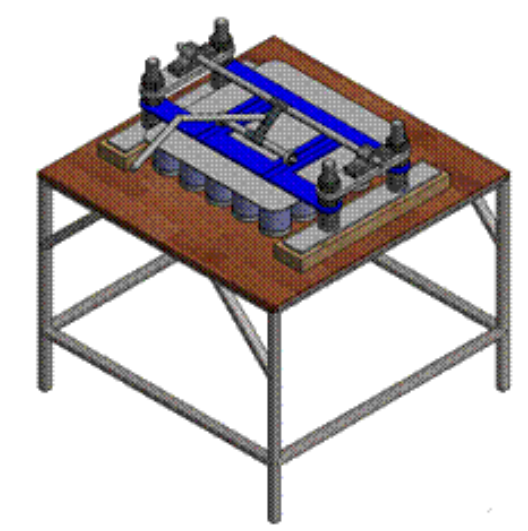

Gambar 4. Konsep Desain Mesin Pencetak Kerupuk Ubi

\section{Pembuatan komponen dan prototipe cetakan mekanis}

Pada tahap ini telah dilakukan proses produksi komponen dari prototipe cetakan mekanis. Pada Gambar 5 terlihat mesin pencetak kerupuk ubi dan hasil cetakan kerupuk ubi.

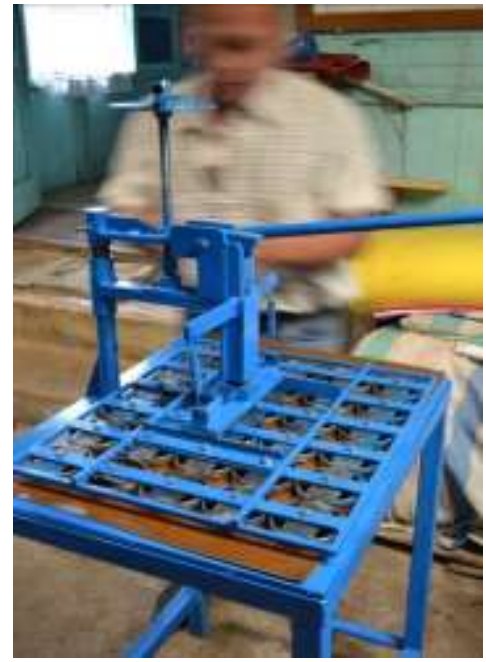

(a)

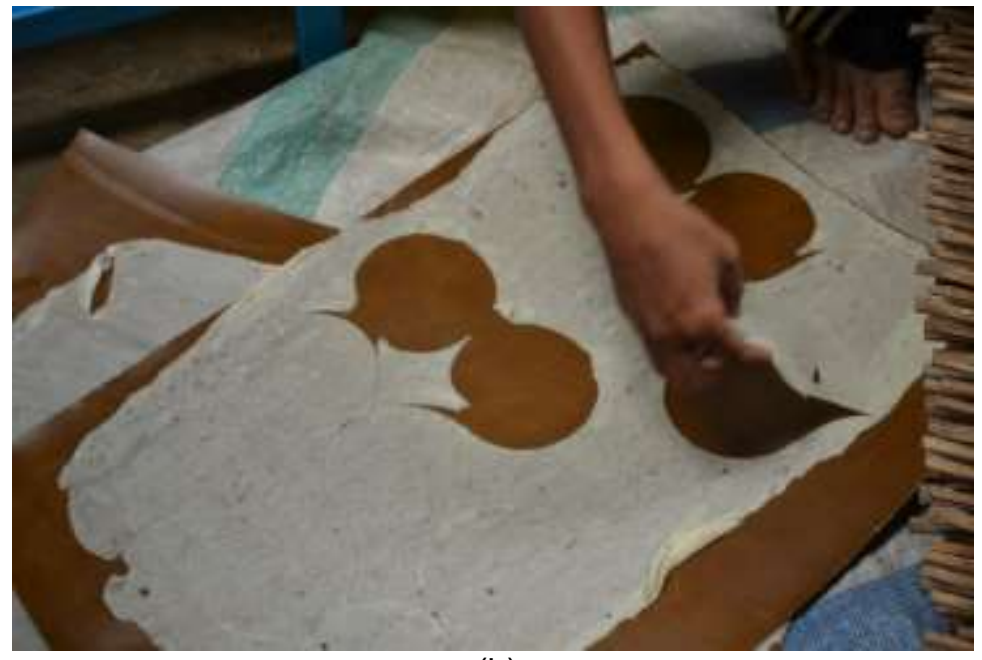

(b)

Gambar 5. (a) Mesin pencetak kerupuk ubi mekanis model, (b) hasil cetakan kerupuk ubi

\section{Hasil Implementasi Model}

Dengan adanya kerjasama sinergis yang dilakukan oleh kedua mitra, IRT Karya Muda sudah mampu memenuhi permintaan distributor besar sentra oleh-oleh Sumatera Barat akibat pasokan yang diberikan oleh IRT Yelmi. RT Karya Muda telah sanggup memenuhi permintaan distributor besar dengan jumlah permintaan rata-rata meningkat hingga 2 kali lipat yaitu 600 bungkus per bulan. IRT Yelmi telah dapat memperkerjakan tenaga ibu rumah tangga yang lain sebanyak 2 orang diluar anggota keluarga. Produksi kerupuk ubi IRT Yelmii meningkat dari produksi sebelumnya yaitu dari $100 \mathrm{~kg}$ ubi/ hari menjadi $200 \mathrm{~kg}$ ubi/perhari. Kerupuk Ubi "RIMA" hasil produksi IRT Karya Muda dan IRT Yelmi dapat ditemukan di Sentra OlehOleh Sumatera Barat seperti Kripik Balado Christine Hakim, Shirley dan Mahkota. 

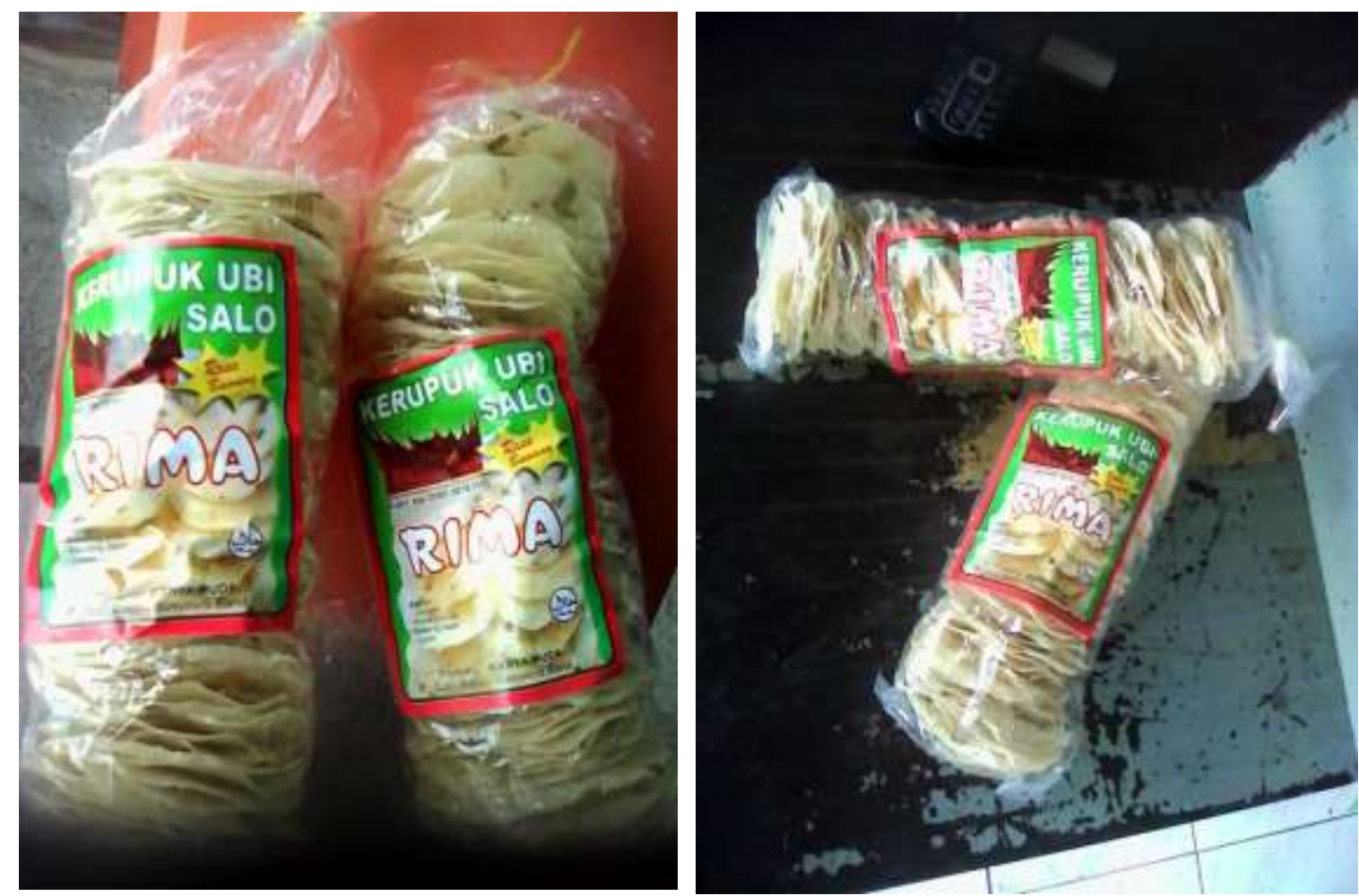

Gambar 6. Kerupuk Ubi "RIMA" produksi IRT Karya Muda dalam Kemasan

\section{SIMPULAN}

Telah diterapkannya model kerjasama sinergis pada kegiatan pengabdian masyarakat yang dilakukan pada industri kerupuk ubi skala rumah tangga di Kabupaten Agam Sumatera Barat. Hasil implementasi dapat disimpulkan sebagai berikut:

a. IRT Karya Muda telah sanggup memenuhi permintaan distributor besar dengan jumlah permintaan rata-rata meningkat hingga 2 kali lipat yaitu 600 bungkus per bulan.

b. IRT Yelmi telah dapat memperkerjakan tenaga ibu rumah tangga yang lain sebanyak 2 orang diluar anggota keluarga. Produksi kerupuk ubi IRT Yelmii meningkat dari produksi sebelumnya yaitu dari 100 kg ubi/ hari menjadi 200 kg ubi/perhari.

\section{DAFTAR PUSTAKA}

Anonim, 2013,

http://regionalinvestment.bkpm.go.id/ newsipid/id/com

modityarea. php? $\mathrm{ic}=2581 \& \mathrm{ia}=13$

Cross, N., 1994. Engineering Design Methods, 2nd Ed., John wiley \& Sons, Chichester, England

Defita, Yelmi, 2013. Pelaku usaha kerupuk ubi. Jorong Koto Kaciak Magek, Kec. Kamang Magek, Kab. Agam, komunikasi pribadi

Eggert, R.J., 2005. Engineering Design, Pearson Prentice Hall, Upper Saddle River, new Jersey

http://agamkab.go.id/?agam=pertanian, diakses pada tanggal 18 April 2014 